\title{
ANALISIS FAKTOR-FAKTOR YANG MEMPENGARUHI TINGKAT KEMISKINAN DI INDONESIA
}

\author{
Oleh: \\ Baiq Tisniwati \\ Pemerintah Daerah Nusa Tenggara Barat \\ E-mail/No.Hp: baiq_bima@yahoo.co.id
}

\begin{abstract}
Effort to reduce poverty zoom at Indonesian need real been known associate whatever factors or regarding low high it increase beggary at Indonesia, From analisis what does utilize secondary data with Regressions Model approaching Barganda was gotten to usufruct that there is one factor dominant the most regards tall its low foot up beggary at Indonesia, a spark of life number that figures is still was reached its health care application generalization that prop resident productivity in utilised economic activity prop more life reasonable. With equation estimation result that results that each a spark of life number decrease as big as 1 percent potentially raise poverty zoom (indigent population)as big as 6,9 percents or as big as 2.245. 010 soul, so is expected to the fore it can be formulated one effective public policy especially step-up accesses to basic the need as education and health (KB, mother welfare, base infrastructure, food and nutrient), so can reduce poverty zoom at this state and not only just as number decrease just but also ala kualitatif.
\end{abstract}

Keywords: Beggary, A Spark Of Life number.

\begin{abstract}
Abstrak
Upaya untuk mengurangi tingkat kemiskinan di Indonesia perlu diketahui sebenarnya faktor-faktor apa sajakah yang berhubungan atau mempengaruhi tinggi rendahnya tingkat kemiskinan di Indonesia, Dari analisis yang menggunakan data sekunder dengan pendekatan Model Regresi Barganda didapatkan hasil bahwa ada satu factor yang paling dominan mempengaruhi tinggi rendahnya jumlah kemiskinan di Indonesia, angka harapan hidup yang menggambarkan masih belum tercapainya pemerataan pemberian pelayanan kesehatan yang menunjang produktifitas penduduk dalam kegiatan ekonomi guna menunjang hidup yang lebih layak. Dengan hasil estimasi persamaan yang menghasilkan bahwa setiap penurunan angka harapan hidup sebesar 1 persen berpotensi menaikkan tingkat kemiskinan (jumlah penduduk miskin)sebesar 6,9 persen atau sebesar 2.245.010 jiwa, sehingga diharapkan kedepannya dapat diformulasikan sebuah kebijakan publik yang efektif terutama peningkatan akses terhadap kebutuhan dasar seperti pendidikan dan kesehatan (KB, kesejahteraan ibu, infrastruktur dasar, pangan dan gizi), sehingga dapat mengurangi tingkat kemiskinan di negara ini dan tidak hanya sekedar penurunan angka-angka saja melainkan juga secara kualitatif.
\end{abstract}

Kata Kunci : Kemiskinan, angka Harapan Hidup. 


\section{PENDAHULUAN}

Berbagai kondisi yang mendiskripsikan masyarakat miskin seperti masih banyaknya anak-anak menderita kekurangan gizi, tingkat kesehatan yang buruk, tingkat buta huruf yang tinggi, lingkungan yang buruk dan masih kurangnya akses infrastruktur maupun pelayanan publik. Daerah kantong-kantong kemiskinan tersebut menyebar diseluruh wilayah Indonesia dari dusun-dusun di dataran tinggi, masyarakat tepian hutan, desa-desa kecil yang miskin, masyarakat nelayan ataupun daerah-daerah kumuh di perkotaan.

Salah satu akar permasalahan kemiskinan di Indonesia yakni tingginya disparitas antar daerah dan golongan masyarakat, akibat tidak meratanya distribusi pendapatan, sehingga kesenjangan antara masyarakat kaya dan masyarakat miskin di Indonesia semakin melebar. Pemerintah sendiri selalu mencanangkan upaya penanggulangan kemiskinan dari tahun ketahun, namun tingkat kemiskinan di Indonesia tidak juga mengalami penurunan yang signifikan, walaupun data di BPS menunjukkan kecenderungan penurunannya, namun secara kualitatif belum menampakkan dampak perubahan yang nyata malahan kondisinya semakin memprihatinkan tiap tahunnya.

Dengan terjadinya krisis moneter pada tahun 1997 telah mengakibatkan jumlah penduduk miskin kembali membengkak dan kondisi tersebut diikuti pula dengan menurunnya pertumbuhan ekonomi yang cukup tajam. Berbagai upaya penanggulangan kemiskinan yang telah diambil pemerintah berfokus pada: Pemberdayaan masyarakat lewat Program Nasional Pemberdayaan Masyarakat (PNPM) yang bertujuan untuk membuka kesempatan berpartisipasi bagi masyarakat miskin dalam proses pembangunan dan meningkatkan peluang dan posisi tawar masyarakat miskin, peningkatan akses terhadap kebutuhan dasar seperti pendidikan dan kesehatan (KB, kesejahteraan ibu, infrastruktur dasar, pangan dan gizi), peningkatan pertumbuhan ekonomi yang berkualitas melalui upaya padat karya, perdagangan ekspor serta pengembangan UMKM, 
serta perbaikan sistem bantuan dan jaminan sosial lewat Program Keluarga Harapan (PKH). Beberapa proyek pemberdayaan masyarakat antara lain $\mathrm{P} 2 \mathrm{KP}, \mathrm{PPK}, \mathrm{CERD}$, SPADA, PEMP, WSSLIC, dan P2MPD.

Untuk mengurangi tingkat kemiskinan di Indonesia perlu diketahui sebenarnya faktor-faktor apa sajakah yang berhubungan atau mempengaruhi tinggi rendahnya tingkat kemiskinan di Indonesia sehingga kedepannya dapat diformulasikan sebuah kebijakan publik yang efektif untuk mengurangi tingkat kemiskinan di negara ini.

Permasalahan utama dalam upaya pengentasan kemiskinan di Indonesia saat ini terkait dengan adanya fakta bahwa pertumbuhan ekonomi tidak tersebar secara merata di seluruh wilayah Indonesia, ini dibuktikan dengan tingginya disparitas pendapatan antar daerah. Selain itu kemiskinan juga merupakan sebuah hubungan sebab akibat (kausalitas melingkar) artinya tingkat kemiskinan yang tinggi terjadi karena rendahnya pendapatan perkapita, pendapatan perkapita yang rendah terjadi karena investasi perkapita yang juga rendah. Tingkat investasi perkapita yang rendah disebabkan oleh permintaan domestik perkapita yang rendah juga dan hal tersebut terjadi karena tingkat kemiskinan yang tinggi dan demikian seterusnya, sehingga membentuk sebuah lingkaran kemiskinan sebagai sebuah hubungan sebab dan akibat (teori Nurkse, 1952) dan telah dibuktikan untuk contoh kasus lingkar kemiskinan di Indonesia (Sumanta, Jurnal Kebijakan Ekonomi; 2005)

Untuk mengetahui tepat atau tidaknya berbagai kebijakan dalam pengentasan kemiskinan di Indonesia maka perlu diketahui faktor-faktor yang melingkupi kemiskinan itu sendiri sehingga dapat diprediksikan penurunan tingkat kemiskinan dimasa yang akan datang.

\section{METODE PENELITIAN}

Untuk sampai pada tujuan tersebut maka data yang digunakan adalah data sekunder yaitu data-data yang dipublikasikan oleh instansi Badan Pusat Statistik Indonesia, ADB dan World Bank, Alat analisa yang digunakan adalah metode 
analisis regresi berganda (multiple regression) dengan menentukan variabel-variabel yang mempengaruhi masing-masing

fungsi tersebut.

Ruang lingkup analisa ini diambil dengan alasan bahwa ada kekhawatiran angka kemiskinan akan kembali meningkat dan bertambah di Indonesia tidak hanya secara kuantitatif namun juga secara kualitatif, jika tidak segera diambil langkah strategis dan komprehensif dalam upaya pengentasannya. Sedangkan Data-data yang diambil antara tahun 1990-2009.

Seiring dengan semakin kompleksnya faktor penyebab, indikator maupun permasalahan lain yang melingkupinya. Defenisi tentang kemiskinan telah mengalami perluasan, Kemiskinan tidak lagi hanya dianggap sebagai dimensi ekonomi melainkan telah meluas hingga kedimensi sosial, kesehatan, pendidikan dan politik. Menurut Badan Pusat Statistik, kemiskinan adalah ketidakmampuan memenuhi standar minimum kebutuhan dasar yang meliputi kebutuhan makan maupun non makan.
Membandingkan tingkat konsumsi penduduk dengan garis kemiskinan atau jumlah rupiah untuk konsumsi orang perbulan. Defenisi menurut UNDP dalam Cahyat (2004), adalah ketidakmampuan untuk memperluas pilihan-pilihan hidup, antara lain dengan memasukkan penilaian tidak adanya partisipasi dalam pengambilan kebijakan public sebagai salah satu indikator kemiskinan. Pada dasarnya defenisi kemiskinan dapat dilihat dari dua sisi, yaitu: a) Kemiskinan absolute: Kemiskinan yang dikaitkan dengan perkiraan tingkat pendapatan dan kebutuhan yang hanya dibatasi pada kebutuhan pokok atau kebutuhan dasar minimum yang memungkinkan seseorang untuk hidup secara layak. Dengan demikian kemiskinan diukur dengan membandingkan tingkat pendapatan orang dengan tingkat pendapatan yang dibutuhkan untuk memperoleh kebutuhan dasarnya yakni makanan, pakaian dan perumahan agar dapat menjamin kelangsungan hidupnya. b) Kemiskinan relatif: Kemiskinan dilihat dari aspek ketimpangan sosial, karena ada orang yang sudah dapat memenuhi kebutuhan dasar 
minimumnya tetapi masih jauh lebih rendah dibanding masyarakat sekitarnya (lingkungannya). Semakin besar ketimpangan antara tingkat penghidupan golongan atas dan golongan bawah maka akan semakin besar pula jumlah penduduk yang dapat dikategorikan miskin, sehingga kemiskinan relatif erat hubungannya dengan masalah distribusi pendapatan. Menurut Todaro (1997) menyatakan bahwa variasi kemiskinan dinegara berkembang disebabkan oleh beberapa faktor, yaitu Perbedaan geografis, jumlah penduduk dan tingkat pendapatan, Perbedaan sejarah, sebagian dijajah oleh Negara yang berlainan, Perbedaan kekayaan sumber daya alam dan kualitas sumber daya manusianya, Perbedaan peranan sektor swasta dan negara, Perbedaan struktur industri, Perbedaan derajat ketergantungan pada kekuatan ekonomi dan politik negara lain dan Perbedaan pembagian kekuasaan, struktur politik dan kelembagaan dalam negeri.

Sedangkan menurut Jhingan (2000), mengemukaan tiga ciri utama Negara berkembang yang menjadi penyebab dan sekaligus akibat yang saling terkait pada kemiskinan. Pertama, prasarana dan sarana pendidikan yang tidak memadai sehingga menyebabkan tingginya jumlah penduduk buta huruf dan tidak memiliki ketrampilan ataupun keahlian. Ciri kedua, sarana kesehatan dan pola konsumsi buruk sehingga hanya sebahagian kecil penduduk yang bisa menjadi tenaga kerja produktif dan yang ketiga adalah penduduk terkonsentrasi di sektor pertanian dan pertambangan dengan metode produksi yang telah usang dan ketinggalam zaman.

Untuk mengukur kemiskinan, Indonesia melalui BPS menggunakan pendekatan kebutuhan dasar (basic needs) yang dapat diukur dengan angka atau hitungan Indeks Perkepala (Head Count Index), yakni jumlah dan persentase penduduk miskin yang berada di bawah garis kemiskinan. Garis kemiskinan ditetapkan pada tingkat yang selalu konstan secara riil sehingga kita dapat mengurangi angka kemiskinan dengan menelusuri kemajuan yang diperoleh dalam mengentaskan kemiskinan di sepanjang waktu. Salah satu cara mengukur kemiskinan yang diterapkan di 
Indonesia yakni mengukur derajat ketimpangan pendapatan diantara masyarakat miskin, seperti koefisien Gini antar masyarakat miskin (GP) atau koefisien variasi pendapatan (CV) antar masyarakat miskin (CVP). Koefisien Gini atau CV antar masyarakat miskin tersebut penting diketahui karena dampak guncangan perekonomian pada kemiskinan dapat sangat berbeda tergantung pada tingkat dan distribusi sumber daya diantara masyarkat miskin.

Aksioma-aksioma atau prinsip-prinsip untuk mengukur kemiskinan, yakni: anonimitas, independensi, maksudnya ukuran cakupan kemiskinan tidak boleh tergantung pada siapa yang miskin atau pada apakah negara tersebut mempunyai jumlah penduduk yang banyak atau sedikit. Prinsip monotenisitas, yakni bahwa jika kita memberi sejumlah uang kepada seseorang yang berada dibawah garis kemiskinan, jika diasumsikan semua pendapatan yang lain tetap maka kemiskinan yang terjadi tidak mungkin lebih tinggi dari pada sebelumnya. Prinsip sensitivitas distribusional menyatakan bahwa dengan semua hal lain konstan, jika anda mentransfer pendapatan dari orang miskin ke orang kaya, maka akibatnya perekonomian akan menjadi lebih miskin.

Dua indeks kemiskinan yang sangat sering digunakan karena memenuhi empat kriteria tersebut adalah Indeks Send dan Indeks Foster-Greer-Thorbecke $\quad(F G T)(P$ alpa). UNDP selain mengukur kemiskinan dengan parameter pendapatan pada tahun 1997 memperkenalkan apa yang disebut Indeks Kemiskinan Manusia (IKM) (Human PovertyIndeks-HPI) atau biasa juga disebut Indeks Pembangunan Manuisia (HumanDevelopment Indeks-HDI), yakni bahwa kemiskinan harus diukur dalam satuan hilangnya tiga hal utama (theree key deprivations), yaitu kehidupan, pendidikan dan ketetapan ekonomi.

\section{Pertumbuhan Ekonomi}

Pertumbuhan ekonomi menunjukkan sejauh mana aktivitas perekonomian akan menghasilkan tambahan pendapatan masyarakat pada suatu periode tertentu. Perekonomian dianggap mengalami pertumbuhan bila seluruh balas jasa riil terhadap penggunaan faktor 
produksi pada tahun tertentu lebih besar daripada pendapatan riil masyarakat pada tahun sebelumnya. Indikator yang digunakan untuk mengukur pertumbuhan ekonomi adalah tingkat pertumbuhan Produk Domestik Bruto (PDB) riil. Dari berbagai teori pertumbuhan yang ada yakni teori Harold Domar, Neoklasikal dari Solow, dan teori Endogen oleh Romer maka dapat diambil kesimpulan

bahwa terdapat tiga faktor utama dalam pertumbuhan ekonomi, yakni Akumulasi modal yang meliputi semua bentuk atau jenis investasi baru, pertumbuhan penduduk dan kemajuan teknologi.

Dalam kaitannya dengan kemiskinan diharapkan sumbersumber pertumbuhan tersebut dapat menurunkan kemiskinan. Investasi melalui penyerapan tenaga kerjanya baik oleh swasta maupun oleh pemerintah, perkembangan teknologi yang semakin inovatif dan produktif dan pertumbuhan penduduk melalui peningkatan modal manusia (humancapital).

Para ekonom pada umumnya membedakan dua ukuran pokok distribusi pendapatan, yang keduanya digunakan untuk tujuan analitis dan kuantitatif, yakni distribusi ukuran dan distribusi fungsional. Distribusi pendapatan perseorangan (personal distribution of income) atau distribusi ukuran pendapatan (size distribution of income) merupakan ukuran yang secara langsung menghitung jumlah penghasilan yang diterima oleh setiap individu atau rumah tangga, biasanya semua individu diurut berdasarkan pendapatan yang diterimanya, lantas membagi total populasi menjadi sejumlah kelompok atau ukuran dengan menggunakan Rasio Kuznets.

Metode yang lazim digunakan untuk menganalisis statistik pendapatan perorangan adalah dengan Kurva Lorenz yang memperlihatkan hubungan kuantitatif aktual antara persentase penerima pendapatan dengan persentase pendapatan total yang benar-benar mereka terima selama periode waktu tertentu. Jika Kurva Lorenznya semakin melengkung mendekati sumbu horizontal bagian bawah maka berarti tingkat ketimpangan distribusi pendapatan disuatu negara semakin parah. 
Terakhir untuk mengukur derajat ketimpanganm pendapatan relatif yakni dengan menghitung rasio bidang yang terletak antara garis diagonal dan Kurva Lorenz dibagi dengan luas separuh segi empat dimana Kurva Lorenz itu berada, dikenal dengan nama Koefisien Gini. Distribusi fungsional atau distribusi pendapatan perfaktor produksi berfokus pada bagian dari pendapatan nasional yang diterima oleh nasing-masing factor produksi (tanah, kerja dan modal) yakni dengan mempersoalkan persentase penghasilan tenaga kerja secara keseluruhan dan membandingkannya dengan persentase pendapatan total yang dibagikan dalam bentuk sewa, bunga dan laba, sehingga setiap factor produksi akan menerima pembayaran mereka mereka sesuai dengan kontribusi mereka pada ouptput nasional.

Aksioma-aksioma penting atau prinsip untuk mengukur tingkat pemerataan hal hal lain diluar pendapatan, yakni: anonimitas, bahwa ukuran ketimpangan seharusnya tidak tergantung pada siapa yang mendapatkan pendapatan yang lebih tinggi, independensi skala, bahwa ukuran ketimpangan kita seharusnya tidak tergantung pada ukuran suatu perekonomian atau negara, prinsip independensi populasi, bahwa pengukuran ketimpangan seharusnya tidak didasarkan pada jumlah penerima pendapatan (jumlah penduduk) dan prinsip transfer (Pigou-Daiton), bahwa dengan mengasumsikan semua pendapatan yang lain konstan, jika kita mentransfer sejumlah pendapatan dari orang kaya ke orang miskin, maka akan dihasilkan dsitribusi pendapatan baru yang lebih merata.

Penduduk Indonesia adalah jumlah orang yang mendiami wilayah Indonesia dalam jangka waktu tertentu dan menetap di Indonesia. Pendapatan Domestik Bruto Perkapita Adalah perbandingan total PDB suatu negara dibagi dengan jumlah penduduk di negara tersebut. Pendapatan Domestik Bruto Perkapita dipandang juga dalam mengukur tingkat standar hidup dalam suatu negara dengan PDB perkapita yang tinggi diartikan dengan tingkat kesejahteraan yang tinggi pula, atau sebaliknya. 
Angka Melek Huruf (dewasa)

adalah proporsi penduduk berusia 15 tahun keatas yang dapat membaca dan menulis dalam huruf latin atau lainnya, dan Angka Harapan Hidup adalah suatu perkiraan rata-rata lamanya hidup sejak lahir yang akan dicapai oleh penduduk dengan asumsi tidak ada perubahan pola mortalitas menurut umur.

Berikut ini adalah data tingkat kemiskinan di Indonesia yang akan kita analisa dengan berbagai faktor yang mempengaruhinya

Tabel 1. Data Tingkat Kemiskinan (TKmiskin), Jumlah penduduk (PDD), Produk Domestik Bruto Perkapita (PDBpita) dan Angka Melek Huruf (AMH), tingkat kesehatan masyarakat (angka harapan hidup)

\begin{tabular}{|c|c|c|c|c|c|}
\hline YEAR & $\begin{array}{c}\text { Kemiskinan } \\
(\%)\end{array}$ & $\begin{array}{c}\text { Jumlah } \\
\text { Penduduk }\end{array}$ & PDBpitariil & $\mathrm{AMH}(\%)$ & $\mathrm{AHH}(\%)$ \\
\hline 1990 & 60,00 & 179.248 .000 & 1.121 .289 & 72,43 & 61,5375 \\
\hline 1991 & 52,02 & 82.940 .000 & 1.317 .983 & 76,23 & 62,066 \\
\hline 1992 & 43,32 & 186.043 .000 & 1.463 .207 & 77,66 & 62,6028 \\
\hline 1993 & 36,22 & 189.136 .000 & 1.578 .416 & 86,73 & 63,167 \\
\hline 1994 & 23,45 & 192.217 .000 & 1.825 .425 & 87,26 & 63,7637 \\
\hline 1995 & 20,35 & 195.283 .000 & 2.124 .062 & 86,26 & 64,3878 \\
\hline 1996 & 17,47 & 198.320 .000 & 2.486 .545 & 87,36 & 65,0263 \\
\hline 1997 & 24,23 & 201.353 .000 & 2.859 .419 & 89,07 & 65,6575 \\
\hline 1998 & 23,43 & 204.393 .000 & 4.380 .095 & 89,42 & 66,2627 \\
\hline 1999 & 19,14 & 207.437 .000 & 4.845 .112 & 89,79 & 66,8351 \\
\hline 2000 & 18,41 & 205.132 .000 & 5.652 .810 & 89,92 & 67,371 \\
\hline 2001 & 18,20 & 208.601 .000 & 6.666 .915 & 89,2 & 67,8723 \\
\hline 2002 & 17,42 & 211.413 .000 & 7.099.977 & 90,71 & 68,3471 \\
\hline 2003 & 16,66 & 214.300 .000 & 7.330 .498 & 90,93 & 68,8023 \\
\hline 2004 & 15,97 & 217.101 .000 & 7.655 .520 & 91,47 & 69,2393 \\
\hline 2005 & 17,75 & 219.852 .000 & 7.999 .375 & 91,91 & 69,6578 \\
\hline 2006 & 16,58 & 222.747 .000 & 8.313 .201 & 92,39 & 70,0566 \\
\hline 2007 & 15,42 & 225.642 .000 & 8.721 .325 & 92,74 & 70,4354 \\
\hline 2008 & 14,15 & 228.523 .000 & 9.111 .134 & 93,05 & 70,7933 \\
\hline 2009 & 14,00 & 231.370 .000 & 9.518 .366 & 93,07 & 70,9833 \\
\hline
\end{tabular}




\section{METODE PENELITIAN}

Metode analisis yang digunakan alat analisis langsung dari hasil eviews dan table dengan memanfaatkan data-data yang tersedia dalam tabel seperti rata-rata, persentase, elastisitas dan ukuran statistik lainnya. Untuk menganalisi faktor-faktor yang mempengaruhi tingkat kemiskinan alat analisa yang digunakan adalah eviews.3, dengan alat ini didapatkan nilai koefisien parameter masing-masing variabel, nilai R-squere, uji signifikansi baik untuk uji masing-masing variabel (uji t) maupun untuk uji variabel secara keseluruhan (uji F). dengan eviews juga dapat diketahui ada tidaknya pelanggaran asumsi baik itu heteroskedastisitas, multikolinearitas maupun autokorelasi. Untuk melihat pengaruh jumlah penduduk, Produk Domestik Bruto, angka melek huruf dan Angka Harapan Hidup maka penulis menggunakan metode analisis regresi berganda (multiple regression) terhadap tingkat kemiskinan (jumlah penduduk miskin) di Indonesia.

Pada regresi berganda peubah tak bebas Y (variable dependen).Tergantung kepada dua atau lebih peubah bebas (variable independent). Garis regresi merupakan garis yang menghubungkan rata-rata dstribusi Y dengan seluruh kemungkinan nilainilai X. Variabel bebas (X) adalah variabel yang nilainya dapat ditentukan dan ditulis pada ruas kiri persamaan. Variabel terikat (Y) adalah suatu variabel sebagai akibat dari perubah yang terjadi pada variable bebas (X). untuk menyatakan kuat tidaknya hubungan linear antara $\mathrm{X}$ dan $\mathrm{Y}$ dapat diukur koefisien korelasi (Coefficient Correlation) atau r. dan untuk dapat mengetahuinya besarnya sumbangan (pengaruh) dari $\mathrm{X}$ terhadap perubah Y dapat dilihat dari koefisien determinasi (Coeffisien of Determination) atau R2. Bentuk persamaan regresi liner berganda adalah sebagai berikut:

$$
\begin{aligned}
\mathrm{Yi}= & \beta 0+\beta 1 \mathrm{X} 1 \mathrm{i}+\beta 2 \mathrm{X} 2 \mathrm{i}+ \\
& \beta 3 \mathrm{X} 3 \mathrm{i}+\beta 4 \mathrm{X} 4 \mathrm{i}+ \\
& \mu \ldots \ldots \ldots \ldots \ldots \ldots \ldots \ldots \ldots \ldots \ldots \ldots \ldots \ldots
\end{aligned}
$$

Bentuk persamaan 1 dianggap fungsi model merupakan persamaan linear dimana hubungannya bersifat linear berupa garis lurus, dimana $\mathrm{i}=$ 1,2,3 ...,n, Yi = Tingkat Kemiskinan (TKmiskin), X1i = Jumlah penduduk 
Indonesia pertahun (Jml Pddk), X2i

$=$ Produk Domestik Bruto Perkapita $(\mathrm{PDB}$ pitariil $), \quad \mathrm{X} 3 \mathrm{i}=$ Persentase Angka Melek Huruf (AMH), X4i = Persentase Angka Harapan Hidup $(\mathrm{AHH}), \beta 0=$ Intersept $\beta 1, \beta 2, \beta 3, \beta 4$, merupakan penduga (koefisien regresi) model persamaan dan $\mu$ adalah besaran yang membuat nilai Y menyimpang dari garis regresinya. (koefisien error)

\section{PEMBAHASAN}

Setelah dilakukan pengumpulan data yang berkaitan dengan faktor-faktor yang mempengaruhi jumlah penduduk miskin maka data tersebut diolah dengan menggunakan program eviews, pada tahap awal dilakukan penentuan variabel dependen (variabel terikat) dan independent (variable bebas) dimana :

Variabel dependen $=$ Persentase jumlah penduduk miskin (\%) (Y), Variabel independen $=$ Jumlah penduduk (juta jiwa), Produk Domestik Bruto Perkapita (ribu rupiah), Angka melek huruf (\%) dan Persentase Angka Harapan Hidup (\%). Kemudian ditentukan model persamaan regresinya.
Pada tahap awal dilakukan run data, terdapat beberapa variabel yang tidak signifikan, kemudian dilakukan pengujian dengan transformasi logaritma. Hasil uji transformasi logaritma menunjukkan hasil yang relatif sama dengan uji sebelumnya, dimana masih ada variabel yang belum signifikan,. Oleh karena itu, perlu dilakukan cara lain untuk mengatasi masalah ini yaitu dengan melakukan pengurangan variable data, melalui proses run satu persatu hingga beberapa kali, barulah didapatkan hasil yang signifikan, dari empat variabel yang dipakai hanya 2 variabel bebas yang signifikan nilai probabilitasnya. Kedua variable tersebut yaitu variabel Produk domestik bruto Perkapita dan variable Angka Harapan Hidup.

Untuk mengetahui suatu model sudah baik atau adanya pelanggaran asumsi maka perlu dilakukan uji atau deteksi terhadap setiap pelanggaran asumsi tersebut, dari tampilan eviews diatas telah dilakukan uji asumsi sebagai berikut .Dari hasil uji heteroskedatisitas diatas diketahui nilai probabilitas sebesar 0.425721, jika digunakan 
tingkat kepercayaan $95 \%(\square 5 \%)$ maka nilai $\square=0,05$, maka $\square(0,05)$ $<$ Probabilitas (0.425721) maka terima $\mathrm{H} 0$, artinya homokedastisitas (tidak ada Heterokedastisitas).

Untuk mendeteksi adanya multikolinearitas maka dapat digunakan indicator yaitu $\mathrm{R}$ square yang tinggi, kemudian uji $\mathrm{F}$ signifikan dan uji $\mathrm{t}$ signifikan semuanya. Dari hasil output eviews dapat diketahui nilai $\mathrm{R}$ Square Addjusted sebesar 0.913172 atau sebesar $91 \%$.

Uji F dilakukan dengan menggunakan nilai probabilitas dengan tingkat kepercayaan $95 \%$ ( $\square$ 5\%), dari table eviews nilai probabilitas 0.000000 artinya : $(0,05)>$ Probabilitas $(0.000000)$ tolak $\mathrm{H} 0$ artinya Uji F signifikan.

Kemudian uji $t$ masingmasing variable sebagai berikut : Produk Domestik Bruto Perkapita : $(0,05)>$ Probabilitas (0.0000), artinya signifikan, Angka Harapan Hidup : $\square(0,05) \quad>$ Probabilitas (0.000000), artinya signifikan. Dari ketiga indicator diatas yaitu $\mathrm{R}$ square cukup tinggi, Uji F signifikan, Uji t signifikan, dengan demikian diasumsikan bahwa model persamaan ini tidak ada multikolinearitas atau hubungan antar variabel bebas.

Adanya autokorelasi dapat dilihat dari nilai statistik Durbin Watson (DW) dari eviews diatas, diketahui nilai DW-nya adalah 0.796626, untuk persamaan yang tidak ada autokorelasinya nilai DWnya mendekati atau melebihi 2 sedikit, namun tidak ada batasan dari nilai diatas diasumsikan nilai DW yang nilainya jauh diatas 2 maka baru dianggap ada autokorelasi. Namun dengan nilai DW yang dibawah 2 Untuk membuktikan lebih lanjut maka digunakan uji BreuschGodfrey Serial Correlation LM test.

Dari uji LM test diperoleh hasil dari table eviews nilai probabilitas 0.022056 artinya, jika menggunakan tingkat kepercayaan 95\% ( $\square 5 \%$ ), jika a $<$ probabilitas, maka terima H0 artinya tidak signifikan adanya autokorelasi ( tidak ada autokorelasi), Jika a > probabilitas, maka tolak Ho pada tingkat kepercayaan 95\%, dan ternyata hasilnya adalah $\square(0,05)$ > Probabilitas (0.022056) artinya tolak H0 dan terdapat adanya autokorelasi antar variable bebas. 
Untuk itu, perlu dilakukan perhatian khusus atas masalah autokorelasi ini karena data yang digunakan adalah data time series. Hal yang pertama kali perlu dilakukan adalah mengetahui kestasioneran untuk masing-masing data. Uji formal yang dapat dilakukan adalah dengan uji Dickey Fuller. Adapun hipotesis yang digunakan adalah sebagai berikut Ho $: \delta=0, \mathrm{H} 1: \delta \neq 0$ Dimana, jika kita tidak menolak hipotesis $\delta=0$, maka $\rho=1$. artinya kita memiliki unit root dan data time series Yt tidak stasioner. Adapun hasil differensiasi variable adalah variabel $\mathrm{X} 2 \mathrm{i}$ (PDBpitariil) stasioner pada Differensi 2, dan $\mathrm{X} 4 \mathrm{i} \quad(\mathrm{AHH})$ stasioner pada level.

Hasil regresi menunjukkan uji statistik Durbin-Watsonnya lebih kecil dari hasil estimasi sebelumnya, untuk itu perlu dilakukan uji heterokedastisitas sekali lagi untuk menunjukkan bahwa varians error telah konstan. Dari heterokedastisitas test diperoleh nilai probabilitas 0.059906 artinya, menggunakan tingkat kepercayaan $95 \%$ ( $\square 5 \%$ ), $(0,05)<$ probabilitas (0.059906), maka terima $\mathrm{H} 0$ artinya tidak signifikan adanya autokorelasi (tidak ada autokorelasi).

Model di atas menunjukkan bahwa R-Square sebesar 0.616373 yang menunjukkan bahwa 62 persen variasi tingkat kemiskinan dapat dijelaskan oleh variabel bebas sedangkan sisanya dijelaskan oleh komponen lain.

\section{PEMBAHASAN}

Dari hasil analisa yang dilakukan dengan model persamaan regresi linear berganda yang menunjukkan sensitifitas variable bebas mempengaruhi variable terikat, model persamaan tingkat kemiskinan di Indonesia adalah :

$\mathrm{Y}=1.721344-2.245010 \mathrm{AHH}$, Menjelaskan bahwa variable Angka Harapan Hidup yang paling signifikan mempengaruhi tingkat kemiskinan di Indonesia dibandingkan dengan tiga factor lainnya, adapun besarnya persentase pengaruh variabel angka harapan hidup dapat diketahui dari nilai koefisien variable tersebut, Angka Harapan Hidup $\quad$ : $\quad$ setiap penurunan angka harapan hidup sebesar $1 \%$ dapat menaikkan tingkat 
kemiskinan sebesar $6,9 \%$ atau sebesar 2.245.010 jiwa.

Setelah dilakukan analisa terhadap faktor-faktor yang mempengaruhi jumlah penduduk miskin dengan menggunakan alat analisa eviews, dari 4 variabel yang diduga mempengaruhi tingkat kemiskinan di Indonesia hanya ada 1 yang paling mempengaruhi secara signifikan dibandingkan dengan ketiga faktor lainnya, yakni Angka Harapan Hidup (AHH), dimana hubungan antara tingkat kemiskinan atau jumlah penduduk miskin dengan angka harapan hidup ini bersifat negatif yang artinya setiap ada penurunan angka harapan hidup akan menaikkan jumlah penduduk miskin atau tingkat kemiskinan di Indonesia dan atau sebaliknya, ini bisa dipahami bahwa fakta di lapangan meskipun sudah banyak program pemerintah guna mengentaskan kemiskinan melalui programprogram dibidang kesehatanfaktor biaya yang masih relatif mahal bagi masyarakat tidak mampu dan pelayanan kesehatan gratis melalui kartu miskin juga belum mampu menuntaskan masalah peningkatan kesehatan seperti yang diharapkan.
Berdasarkan pengolahan data dan analisa terhadap faktor-faktor yang mempengaruhi jumlah penduduk miskin di Indonesia dengan menggunakan analisa eviews maka dapat disimpulkan tingkat kemiskinan (jumlah penduduk miskin) sangat dipengaruhi oleh tingkat kesehatan dan gizi yang menunjang angka harapan hidup.

Dari hasil tulisan ini diharapkan kepada pemerintah untuk memperbaiki tingkat kesehatan dan gizi masyarakat dengan membuat kebijakan pengentasan kemiskinan melalui program-program di bidang kesehatan yang lebih nyata dan merata.

\section{DAFTAR PUSTAKA}

Anonymous, Key Indicator for Asia Pacific, Berbagai Edisi, Asian Development Bank

Badan Pusat Statistik 2009, Data Strategis BPS, Berbagai edisi ,Badan Pusat Statistik

Dornbusch, Rudriger dan Stanley Fischer, 1992, Makro Ekonomi Edisi keempat, Terjemahan: oleh J. Mulyadi, Erlangga, Jakarta

Jhingan. (2000), Ekonomi Pembangunan dan Perencanaan. Jakarta, Rajawali Press. 
Kusnadi, Ace. (1998), Faktor-faktor yang Mempengaruhi Pertumbuhan Ekonomi di Jawa Barat Tahun 1983-1996, Skripsi Sarjana (Tidak dipublikasikan), Fakultas Ekonomi, Universitas Islam Indonesia, Yogyakarta.

Mangkoesoebroto, Guritno. (1998) Teori Ekonomi Makro, Yogyakarta, STIE YKPN
Mankiw, Gegory, 2003, TeorI Makroekonomi Edisi Kelima, Terjemahan: oleh Imam Nurmawam SE, Erlangga Jakarta

Nachrowi, Nachrowi Djalal, 2002, Penggunaan Teknik Ekonometri, PT RajaGrafindo Persada, Jakarta

Samuelsen, Paul A \& William D. Nordhaus, (1993), Makro Ekonomi, Erlangga, Jakarta. 